\title{
DETEKSI DAN QUANTIFIKASI BAKTERI PENGHASIL ENZIM FITASE DI SALURAN PENCERNAAN IKAN NILA (Oreochromis niloticus)
}

\section{DETECTION AND QUANTIFICATION OF PHYTASE-PRODUCING BACTERIA ASSOCIATED WITH THE GASTROINTESTINAL TRACT OF NILE TILAPIA (Oreochromis niloticus)}

\author{
Muhamad Amin ${ }^{1 *}$, Mita Ayu Liliyanti ${ }^{1)}$, Juwaidin $^{2}$, Husnawati $^{1)}$, Hasnah $^{3)}$ \\ ${ }^{1)}$ Program Studi Budidaya Perairan, Fakultas Perikanan, Universitas 45 Mataram, \\ Jl. Imam Bonjol Tohpati, Cakranegara, Kota Mataram, Nusa Tenggara Barat, Indonesia \\ ${ }^{2)}$ Laboratorium Mikrobiologi dan Bioteknologi, Fakultas Peternakan Universitas mataram \\ Jl. Majapahit No. 62 Kota Mataram, NTB, Indonesia. \\ ${ }^{3}$ Balai Karantina ikan Pengendalian Mutu dan Keamanan hasil perikanan Mataram. \\ Jl. Adi Sucipto, Ampenan Utara, Ampenan, Kota Mataram, NTB, Indonesia.
}

\begin{abstract}
Abstrak
Penelitian ini bertujuan untuk mendeteksi dan mengkuantifikasi jumlah bakteri penghasil enzim fitase dari saluran pencernaan ikan nila. Ada dua jenis sample yang digunakan, yakni ikan yang dibudidaya dan ikan liar. Hasil penelitian menunjukkan bakteri penghasil enzim fitase hanya dapat dideteksi dari saluran pencernaan ikan budidaya. Sedangkan, pada saluran pencernaan ikan nila liar tidak ditemukan adanya kelompok bakteri penghasi enzim tersebut. Dari total jumlah bakteri yang bersimbiosis dengan saluran pencernaan ikan nila dibudidaya $\left(7.8 \times 10^{7} \mathrm{CFU} / \mathrm{g}\right)$, jumlah bakteri penghasil enzim fitase sebanyak $2.6 \times 10^{6} \mathrm{CFU} / \mathrm{g}$ atau sekitar $3.31 \%$. Hasil penelitian ini mengkonfirmasi adanya bakteri penghasil enzim fitase di saluran pencernaan ikan nila budidaya. Uji lanjut untuk mengetahui kuantitas enzim fitase yang dihasilkan di saluran pencernaan sangat diperlukan untuk mengetahui jumlah asam fitat maksimum yang dapat dicerna. Selain itu, bakteri tersebut harus diidentifikasi untuk dapat mengetahui sumbernya.
\end{abstract}

Kata kunci : Enzim fitase, probiotik, saluran pencernaan.

\begin{abstract}
Phytate content which is considered as anti-nutritional factors has been frequently associated with plant-based diets. One way to dealt with this issue is by supplementation of exogenous phytaseproducing bacteria. Thus, this study was aimed at detection and quantification of phytase-producing bacteria from the gastrointestinal tract of cultured Nile tilapia (Oreochromis niloticus) and wild tilapia. The result showed that phytase-producing bacteria were only detected from the gastrointestinal tract of cultured tilapia, while none was observed from the wild tilapia. Total viable count (TVC) of bacteria associated with the gastrointestinal tract of cultured Tilapia was recorded at $7.8 \times 10^{7} \mathrm{CFU} / \mathrm{g}$, and the number of phytase-producing bacteria were counted for $2.6 \times 10^{6} \mathrm{CFU} / \mathrm{g}$ or about $3.31 \%$. This research result indicated the presence of phytase-producing bacteria in the gastrointestinal tract of Nile tilapia. However, further research is still required to quantify the amount and activity of phytase in the intestinal tract of the fish. In addition, those phytase-producing bacteria should be identified in orderto track where the bacteria came from.
\end{abstract}

Keywords : Phytase, probiotic, the gastrointestinal tract, tilapia

email korespondensi : muhamad.amin81@gmail.com 


\section{Pendahuluan}

Sumber protein alternatif sebagai pengganti tepung ikan terbaik saat ini adalah tepung kedelai. Disamping kandungan protein yang tinggi (46.59\%) (Yamin \& Palinggi 2016) serta profil asam aminonya yang cukup baik, (Kader et al. 2012; Storebakken 2000), tepung kedelai juga memiliki harga yang relatif lebih murah dari tepung ikan. Penggunaa tepung kedelai pada pakan telah dilaporkan di beberapa komoditas budidaya perairan dengan hasil yang signifikan seperti pada karper (Sardar, Randhawa, Abid \& Prabhakar 2007), timun laut (Liao, Ren, He, Han \& Jiang 2015), dan udang (Azarm \& Lee 2014; Ding, Zhang, Ye, Du \& Kong 2015).

Namun, kendala utama yang masih dihadapi dalam penggunaan tepung kedelai adalah adanya kandungan asam fitat senyawa yang tergolong anti-nutrisikarena tidak dapat dicerna oleh ikan (Cho \& Bureau 2001; Harland \& Morris 1995; Reddy, Sathe \& Salunkhe 1982; Al-Asheh \& Duvnjak 1995). Pada saluran pencernaan ikan, senyawa tersebut cenderung aktif untuk mengikat protein dan mineral-mineral esensial (seperti kalsium, magnesium, besi dan seng). Akibatnya adalah rendahnya bioavailabilitas protein dan mineral, serta dapat menghambat kinerja enzim pencernaan (Pallauf \& Rimbach 1997). Disamping itu, fitat juga telah dilaporkan mengurangi daya absoprsi usus ikan terhadap nutrisi, menyebabkan tingginya polusi lingkungan perairan(Conrad, Savchenko, Breves \& Hofemeister 1996). Penelitian sebelumnya melaporkan bahwa asam fitat dapat dipecah oleh enzim yang disebut fitase, dikenal juga dengan mioinositol heksakifosfat fosfohidrolase(Liener 1994; Sardar et al. 2007; Cao et al. 2008).

Beberapa penelitian sebelumnya melaporkan ikan tidak dapat mencerna asam fitat sehingga perlu penambahan enzim fitase untuk mengurangi dampak negatif asam fitat(Cho \& Bureau 2001; Harland \& Morris 1995; Reddy et al. 1982; Al-Asheh \& Duvnjak 1995). Namun, penelitian lain juga ada yang menyebutkan bahwa terdapat beberapa jenis bakteri di saluran penernan ikan yang mampu menghasilkan enzim fitase.Olehkarenanya, penelitian ini bertujuan untuk mendeteksi dan mengkuantifikasi jumlah bakteri penghasil enzim fitase dari saluran pencernaan ikan nila.

\section{Metode Penelitian}

\section{Ikan Sampel dan Pengambilan Usus}

Pengambilan saluran penernaan ikan sampel dilakukan menurut protokol yang di kembangkan oleh Amin (2016) dengan sedikit modifikasi. Secara ringkas, 15 ekor ikan nila dengan berat rata-rata $2.52 \pm 0.70 \mathrm{~g}$ dan panjang $5.05 \pm 0.64 \mathrm{~cm}$ dipelihara di akuarium dan dipuasakan selama 24 jam untuk membersihkan saluran pencernaannya. Ikan tersebut selanjutnya di bunuh degan menusuk bagian kepala. Setelah ikan tidak bergerak, bagian ventral dibilas dengan $1 \%$ cairan iodin, dan usus diambil secara aseptik menggunakan pisau bedah steril. Usus ikan dihomogenisasi dengan mortar dan dicampur kedalam cairan fisiologis (1:9). Cairan yang sudah homogen tersebut kemudian dijadikan inokulum untuk kultur bakteri.

\section{Kultur Bakteri}

Kultur bakteri dilakukan menurut protokol Ali et al. (2015) dengan sedikit modifikasi. Ringkasnya, cairan inokulum (homogenisasi usus) dilakukan 5 seri pengenceran (1:10). Kemudian $100 \mu \mathrm{L}$ sampel diambil dari setiap pengenceran dan dituang pada media TSA dan agar yang mengandung sodium fitat. Adapun komposisi media agar dengan kandungan fitat tersebut adalah; glukosa $10.0 \mathrm{~g} / \mathrm{L} ;\left(\mathrm{NH}_{4}\right) 2 \mathrm{SO}_{4}$ $1.0 \mathrm{~g} / \mathrm{L}$; urea $10 \mathrm{~g} / \mathrm{L}$; asam sitrat $3.0 \mathrm{~g} / \mathrm{L}$; sodium citrate $2.0 \mathrm{~g} / \mathrm{L} ; \mathrm{MgSO}_{4} .7 \mathrm{H}_{2} \mathrm{O} 1.0 \mathrm{~g} / \mathrm{L}$; sodium phytate $3.0 \mathrm{~g} / \mathrm{L} ; 1 \mathrm{M}$ Tris bufer $(\mathrm{pH}$ 8.0) $100 \mathrm{~mL} / \mathrm{L} ; \mathrm{FeSO}_{4} .7 \mathrm{H}_{2} \mathrm{O} 0.1 \mathrm{~g} / \mathrm{L}$; biotin 50 $\mathrm{mg} / \mathrm{L}$; thiamin- $\mathrm{HCl} 20 \mathrm{mg} / \mathrm{L}$; dan agar 15.0 $\mathrm{g} / \mathrm{L}$. Kemudian $\mathrm{pH}$ media diatur menjadi 7 sebelum disterilisasi. Medium agar yang sudah diinokulasi kemudian diinkubasi di suhu ruangan selama 48 jam secara aerobik. Koloni yang tumbuh pada kedua jenis agar dihitung untuk mendapatkan angka Lempel total (ALT) dan proporsi jumlah bakteri penghasil enzim fitase.

\section{Analisis Data}

Data tentang jumlah bakteri di saluran pencernaan ikan yang hidup di lingkungan berbeda akan di analisa dengan t-test dengan bantuan aplikasi SPSS. 


\section{Hasil}

\section{Jumlah Bakteri di Saluran Pencernaan Ikan Liar dan Ikan Budidaya}

Hasil uji angka lempeng total (ALT) menunjukkan bahwa jumlah bakteri yang bersimbiosis dengan ikan nila yang hidup liar lebih banyak dibandingkan dengan ikan yang dibudidaya di kolam, $\mathrm{t}=2.19, \mathrm{df}=14, \mathrm{p}=0.046$. Rata-rata jumlah bakteri yang bersimbiosis dengan ikan liar tercatat sebesar 9.09 log unit. Sedangkan jumlah bakteri yang bersimbiosis dengan usus ikan budidaya sebesar $7.99 \log$ unit (Gambar 1).

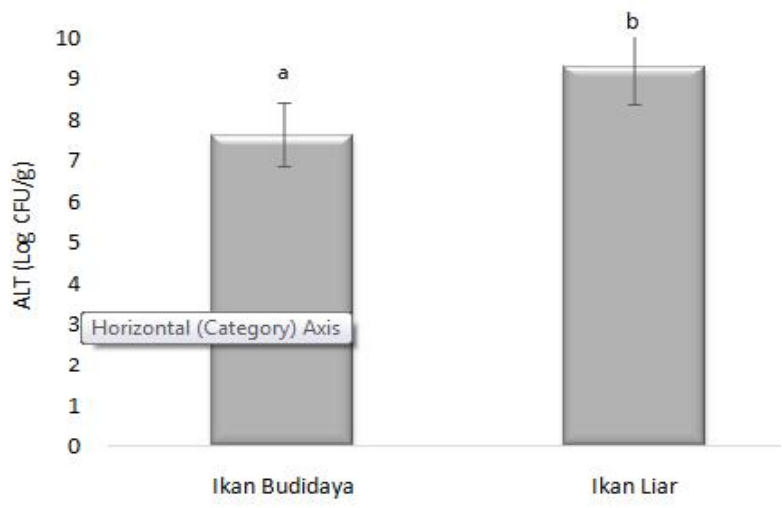

Gambar 1. Jumlah bakteri yang bersimbiosis dengan saluran pencernaan ikan nila yang hidup di kolam budidaya dan saluran pencernaan ikan nila yang hidup liar. Superscript berbeda pada gambar menunjukkan bahwa jumlah bakteri (ALT) pada saluran pencernaan ikan budidaya dan ikan liar berbeda secara signifikan, $\mathrm{p}<0.05$.

\section{Bakteri Penghasil Enzim Fitase}

Dari jumlah tersebut, persentase jumlah bakteri penghasil fitase yang dapat dideteksi dari saluran pencernaan ikan budidaya sebanyak $2.5 \times 10^{6} \pm 4.0 \times 10^{2} \mathrm{CFU} / \mathrm{g}$ atau 6.41 $\pm 0.07 \log$ unit CFU/g atau skitar $3.31 \%$, Gambar 2. Namun, keberadaan bakteri penghasil enzim fitase tersebut ditemukan hanya pada ikan budidaya. Sedangkan, pada saluran pencernaan ikan nila liar tidak ditemukan bakteri penghasil fitase.

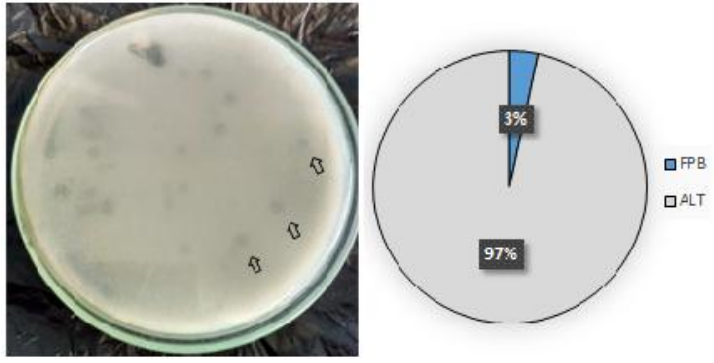

Gambar 2. Proporsi bakteri penghasil enzim fitase terhadap angka lempeng total disaluran pencernaan ikan budidaya. Tanda panah menunjukkan coloni bakteri yang membentuk zona clearance sebagai indikasi adanya aktifitas enzim fitase. FPB adalah proporsi bakteri penghasil enzim fitase, dan ALT adalah jumlah bakteri yang bersimbiosis dengan saluran pencernaan ikan nila.

\section{Pembahasan}

Beberapa penelitian sebelumnya menyebutkan bahwa hewan monogastric seperti ikan tidak mampu mensekresi enzim fitase sehingga tidak dapat mengurai asam fitat, senyawa antinutrisi yang banyak terdapat pada pakan dengan sumber protein dari tanaman (Kumar Singh, Kumar Joshi \& Kishor Gupta 2013; Roy, Mondal \& Ray 2009). Olehkarenanya, keberadaan asam fitatdi pakan sering kali dilaporkan menyebabkan daya cerna pakan menjadi rendah, pertumbuhan ikan lambat dan juga meningkatkan limbah buanganke lingkungan perairan (Ai et al. 2007). Literatur lain menyebutkan bahwa dampak negatif asam fitat dapat diatasi dengan suplementasi enzim fitase atau bakteri penghasil fitase. Akan tetapi, seplementasi enzim maupun bakteri tidak selalu memberikan hasil yang positif dikarenan berbagai faktor seperti karakter enzim maupun bakteri yang sangat peka dengan perubahan kondisi lingkungan khususnya suhu tinggi pada proses pembuatan pakan. Ai et al. (2007) misalnya melaporkan bahwa suplementasi enzim fitase melalui pakan tidak memberikan efek yang signifikan terhadap daya cerna pakan dan pertumbuhan ikan kakap.

Hasil penelitian ini menunjukkan bahwa ada bakteri penghasil enzim fitase yang hidup di saluran pencernaan ikan, meskipun hanya 
3\% dari total bakteri yang ada. Proporsi bakteri yang ditemukan pada penelitian ini sedikit lebih rendah dari proporsi bakteri penghasil enzim fitase pada saluran pencernaan ikan nila yang dilaporakan pada penelitian sebelumnya. Roy et al. (2009) misalnya melaporkan bahwa proporsi bakteri penghasil bakteri penghasil enzim fitase yang dideteksi dari saluran pencernaan ikan nila adalah $4 \%$. Namun hasil penelitian ini juga lebih tinggi dari jumlah bakteri penghasil enzim fitase di saluran pencernaan nila yang hanya $1.3 \%$ (Khan \& Ghosh 2012). Adanya perbedaan angka tersebut kemungkinan disebabkan oleh ukuran ikan sampel yang digunakan. Khan \& Ghosh (2012)menggunakan ikan nila dengan berat rata-rata 22.33 grdan panjang rata-rata $9.34 \mathrm{~cm}$. Roy et al. (2009) bahkan menggunakan ikan nila yang jauh lebih besar yakni berat rata-rata 89 gr dan panjang rata-rata $13.6 \mathrm{~cm}$. Sedangkan ikan nila yang digunakan pada penelitian ini memiliki berat rata-rata hanya $2.52 \pm 0.70$ gr dan panjang $5.05 \mathrm{~cm}$. Selain itu, perbedaan yang ada juga dapat disebabkan oleh kondisi lingkungan ikan sampel.

Hasil penelitian ini dan penelitian sebelumnya menunjukkan bahwa adanya sejumlah bakteri penghasil enzim fitase yang hidup di dalam saluran pencernaan ikan nila. Persamaan penelitian ini dan penelitian sebelumnya tersebut adalah adanya bakteri penghasil enzim fitase yang hidup di saluran pencernaan ikan nila.Hal ini mengindikasikan bahwa pendekatan lain seperti aplikasi prebiotik, suplementasi nutrisi yang dibutuhkan oleh kelompok bakteri tersebut, sangat memungkinkan untuk dilakukan

\section{Kesimpulan}

Hasil penelitian ini menunjukkan adanya bakteri penghasil enzim fitase yang hidup di saluran pencernaan ikan nila budidaya. Hasil lainnya menunjukkan bahwa keberadaan bakteri penghasil ezim fitase tidak dapat dideteksi dari saluran pencernaan ikan nila yang hidup liar. Jumlah bakteri penghasil enzim fitase sebanyak $2.6 \times 10^{6} \mathrm{CFU} / \mathrm{g}$ atau sekitar $3.31 \%$. Penelitian lebih lanjut tentang aktifitas enzim fitase disaluran pencernaan ikan nila sangat direkomendasikan untuk mengetahui kapasitas mencerna asam fitat.

\section{Ucapan Terima Kasih}

Penulis mengucapkan banyak terimakasih kepada Kementrian Riset, Teknologi dan Pendidikan Tinggi (Kemenristekdikti) atas supportnya dalam bentuk pendanaan melalui skema Penelitian Dosen Pemula (PDP) tahun anggaran 2018.

\section{Daftar Pustaka}

Ai, Q., Mai, K., Zhang, W., Xu, W., Tan, B., Zhang, C., \& Li, H. (2007). Effects of exogenous enzymes (phytase, non-starch polysaccharide enzyme) in diets on growth, feed utilization, nitrogen and phosphorus excretion of Japanese seabass, Lateolabrax japonicus. Comparative Biochemistry and Physiology, Part A: Molecular \& Integrative Physiology,147, 502-508. doi:http://dx.doi.org/10.1016/j.cbpa.2007.0 1.026

Al-Asheh, S., \& Duvnjak, Z. (1995). The effect of phosphate concentration on phytase production and the reduction of phytic acid content in canola meal by Aspergillus carbonarius during a solidstate fermentation process. Applied microbiology and biotechnology,43, 25-30.

Ali, M., Depamede, S. N., Setyono, B. D., Mukhlis, A., Amin, M., \& Ashari, M. (2015). Stirred bioreactor for the robustness production of recombinant gst. Vp28 in fed-batch cultivation of Escherichia coli. Scientific Study \& Research. Chemistry \& Chemical Engineering, Biotechnology, Food Industry, 16, 245.

Amin, M. (2016). Screening of CelluloseDegrading Bacteria Associated with Gastrointestinal Tract of Hybrid Abalone as Probiotic Candidates. International Journal of doi:10.5376/ija.2016.06.0010 Aquaculture, 6 .

Azarm, H. M., \& Lee, S. M. (2014). Effects of partial substitution of dietary fish meal by fermented soybean meal on growth performance, amino acid and biochemical parameters of juvenile black sea bream Acanthopagrus schlegeli. Aquaculture Research,45, 994-1003.

Cao, L., Yang, Y., Wang, W., Yakupitiyage, A., Yuan, D., \& Diana, J. (2008). Effects of pretreatment with microbial phytase on phosphorous utilization and growth 
performance of Nile tilapia (Oreochromis niloticus). Aquaculture Nutrition,14, 99109.

Cho, C., \& Bureau, D. (2001). A review of diet formulation strategies and feeding systems to reduce excretory and feed wastes in aquaculture. Aquaculture research,32, 349-360.

Conrad, B., Savchenko, R. S., Breves, R., \& Hofemeister, J. (1996). A T7 promoterspecific, inducible protein expression system forBacillus subtilis. Molecular and General Genetics MGG,250, 230-236.

Ding, Z., Zhang, Y., Ye, J., Du, Z., \& Kong, Y. (2015). An evaluation of replacing fish meal with fermented soybean meal in the diet of Macrobrachium nipponense: growth, nonspecific immunity, and resistance to Aeromonas hydrophila. Fish \& shellfish immunology,44, 295-301.

Harland, B. F., \& Morris, E. R. (1995). Phytate: a good or a bad food component? Nutrition Research,15, 733-754.

Kader, M. A., Bulbul, M., Koshio, S., Ishikawa, M., Yokoyama, S., Nguyen, B. T., \& Komilus, C. F. (2012). Effect of complete replacement of fishmeal by dehulled soybean meal with crude attractants supplementation in diets for red sea bream, Pagrus major. Aquaculture,350353 , 109-116. doi:http://dx.doi.org/10.1016/j.aquaculture. 2012.04.009

Khan, A., \& Ghosh, K. (2012). Characterization and identification of gutassociated phytase-producing bacteria in some fresh water fish cultured in ponds. Acta Ichthyol Piscat,42, 37-45. doi:http://dx.doi.org/10.3750/AIP2012.42.1 .05

Kumar Singh, N., Kumar Joshi, D., \& Kishor Gupta, R. (2013). Isolation of phytase producing bacteria and optimization of phytase production parameters. Jundishapur Journal of Microbiology,6, 1-6.
Liao, M., Ren, T., He, L., Han, Y., \& Jiang, Z. (2015). Optimum dietary proportion of soybean meal with fish meal, and its effects on growth, digestibility, and digestive enzyme activity of juvenile sea cucumber Apostichopus japonicus. Fisheries Science,81, 915-922. doi:http://dx.doi.org/10.1007/s12562-0150916-1

Liener, I. E. (1994). Implications of antinutritional components in soybean foods. Critical Reviews in Food Science \& Nutrition,34, 31-67.

Pallauf, J., \& Rimbach, G. (1997). Nutritional significance of phytic acid and phytase. Archives of Animal Nutrition,50, 301-319.

Reddy, N., Sathe, S., \& Salunkhe, D. (1982). Phytates in legumes and cereals. Advances in food research,28, 1-92.

Roy, T., Mondal, S., \& Ray, A. K. (2009). Phytase-producing bacteria in the digestive tracts of some freshwater fish. Aquaculture Research,40, 344-353. doi:DOI 10.1111/j.1365-2109.2008.02100.x

Sardar, P., Randhawa, H., Abid, M., \& Prabhakar, S. (2007). Effect of dietary microbial phytase supplementation on growth performance, nutrient utilization, body compositions and haemato biochemical profiles of Cyprinus

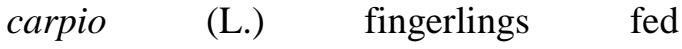
soyprotein based diet. Aquaculture Nutrition, 13, 444-456.

Storebakken, T. (2000). Soy products as fat and protein sources in fish diets for intensive aquaculture. Soy in animal nutrition.

Yamin, M., \& Palinggi, N. N. (2016). Aktivitas enzim protease dan kondisi pencernaan di usus ikan kerapu macam (Epinephelus fuscoguttatus) setelah pemberian pakan. Jurnal Riset Akuakultur,2, 281-288. 